\title{
Könyvtárhasználók igényeire szabott szolgáltatásfejlesztés az Egyetemi Könyvtárban
}

\section{Az elözmények}

Az Egyetemi Könyvtári Szolgálat (továbbiakban EKSz) K21 minőségfejlesztési projektje rendszeres időközönként végez olvasói és oktatói igényfelméréseket, elégedettségméréseket. Emellett az Egyetemi Könyvtár saját projektjeihez kapcsolódva is végzett hasonló felméréseket, melyek részben a könyvtár szolgáltatásaira kérdeztek rá.

A kérdésekre adott válaszok egy része egyértelmúen rámutatott arra, hogy szükség van a hagyományos dokumentumkikérés folyamatának változtatására, és ezt megerősítették a napi könyvtárhasználatban az olvasók visszajelzései és a könyvtárosok tapasztalatai is.

\section{A hagyományos dokumentumkikérés}

Az Egyetemi Könyvtár állományának viszonylag nagy, 90\% feletti része zárt raktárakban található, ahová az olvasó nem mehet be. A dokumentumok kikérése ezekből a raktárakból kizárólag papíralapú kérőlap kitöltésével lehetséges. Attól függően, hogy kölcsönzésre vagy helyben olvasásra kéri ki valaki a példányokat, más-más kérölapot kell kitölteni, amelyekre fel kell vinni a dokumentum egyes adatait. Ezek az adatok eltérők lehetnek bizonyos dokumentumtípusok esetén, például más adatot kell ráírni könyv, kézirat vagy időszaki kiadvány esetén. Amit minden dokumentumnál szükséges megadni, az a jelzet, mely a dokumentum egyedi azonosítója.

A hagyományos dokumentumkikérés lépéseinek vázlata:

- a dokumentumhoz tartozó adatok (például szerző, cím, kiadási év, évfolyam, dátum + jelzet kikeresése a könyvtár elektronikus (web-OPAC), illetve valamely papír katalógusából;

- a papíralapú kérőlap(ok) kitöltése önállóan vagy könyvtáros segítségét igénybe véve;

- kérőlap(ok) raktárba juttatása könyvtáros vagy raktáros által.

A kérölap kitöltése gyakran könyvtáros segítséggel valósul meg az olvasók telefonon bediktált, vagy e-mailben elküldött információi alapján. 
A felmérésekre adott használói visszajelzések egybecsengtek a könyvtárosok észrevételeivel: mivel a Könyvtárhasználati Szabályzatban foglaltak szerint egy olvasónak, olvasói státusztól függően, lehetősége van akár 20-30 dokumentumot is kikérni, ezért a telefonos megkeresések, $\mathrm{s}$ az ezek következtében a könyvtárosra háruló adminisztráció jelentősen lassítja a kiszolgálást. Emellett az is sokszor előfordul a közönségszolgálatban, hogy csak egyedül teljesít szolgálatot valamely kolléga, minden további felmerülő helyzet megoldásáért is felelve. Szükséges tehát a munkafolyamatok optimalizálása.

\section{A fejlesztés 1. szakasza}

A beérkezett visszajelzések alapján felülvizsgálatra került a hagyományos dokumentumkikérés folyamata, ezzel együtt kialakítottuk az elektronikus ügyintézés tervezett lépéseit is. Meghatároztuk, hogy a fejlesztésnek mind az angol, mind a magyar felületen párhuzamosan kell haladnia a web-OPAC-on, és azt is, hogy minden lépést több böngészőből indulva is ellenőrizni kell, hogy a felhasználók megfelelő tartalmat és megjelenítést lássanak.

Az elektronikus dokumentumkikérés tervezett lépései:

- beiratkozás - azonosító rendelése az olvasó nevéhez,

- bejelentkezés a web-OPAC katalógusba,

- dokumentumkeresés a web-OPAC katalógusban,

- dokumentum kiválasztása,

- dokumentum kikérése online,

- a kérőlap nyomtatása az 1 . és a 4. emeleten elhelyezett nyomtatók valamelyikén.

\section{A fejlesztés 2. szakasza}

A hagyományos dokumentumkikérés folyamatának vizsgálata, a fejlesztendő, nem hatékony pontok megjelölése, valamint az elektronikus dokumentumkikérés tervezett lépéseinek meghatározásával egy időben történt meg az erőforrások felmérése. Személyi, eszköz és anyagi oldalról vizsgáltuk meg a rendelkezésre álló forrásokat.

Látogatást tettünk az Aleph IKR magyarországi forgalmazójánál, az Ex-Lh Számítástechnikai Kft.-nél. Velük több megbeszélésen vettünk részt, ahol tájékoztatást kaptunk a rendszer nyújtotta lehetőségekről, a működésről és az árakról. 
Figyelembe véve az igényeinket, az erőforrásainkat és a rendszer adta lehetőségeket, többszöri egyeztetés után hoztuk meg a döntést arról, hogy melyik verziót választjuk ki és alakítjuk tovább.

A jó gyakorlatok átvétele okán látogatást tettünk két olyan könyvtárban, ahol már müködik az elektronikus dokumentumkikérés. Először a BME OMIKK-ba, majd az Országgyülési Könyvtárba mentünk el, mindkét könyvtárban Aleph-rendszert használnak, ugyanaz a fejlesztő csoport segíti őket. Az Országgyülési Könyvtárban nemcsak olvasói oldalról, hanem informatikai oldalról is meg tudtuk nézni a kikérés müködését, menetét és a tapasztalatokat, javaslatokat is hallottuk.

\section{A fejlesztés 3. szakasza}

Az Aleph-beli módosítások első lépése az új gyüjtemények kialakítása volt. Ennek keretében a korábbi „U=EK raktár” gyüjteményt kellett a jelzettartományok pontos megadásával szétbontani úgy, hogy az egyes raktárszinteknek egy-egy gyüjtemény feleljen meg. Ennek oka az volt, hogy minden egyes dokumentum esetében meg kellett tudni mondani és be kellett állítani az Aleph-ben, hogy a hozzá tartozó kérőlap nyomtatása az első vagy a negyedik emeleti nyomtatón történjen. Így létrejöttek az „U1=EK raktár 1”, „U2=EK raktár 2”, „U3=EK raktár 3”, „,U4=EK raktár 4”, „U5=EK raktár 5”, „U6=EK raktár 6”, „U7=EK raktár 7”, „,U8=EK raktár 8”, „U9=EK raktár 9” és „U10=EK raktár 10” gyüjtemények. A gyüjtemények számozásakor figyelembe vettük azt is, hogy az egyes raktárszinteken belül is vannak újabb szintek, ezek mindegyike külön számot kapott.

A gyüjtemények kialakítása után történt az Aleph-en belül a példányok mozgatása az „U=EK raktár” gyüjteményböl a jelzetnek megfelelő új gyüjteménybe. Ennek végeztével az „U=EK raktár” gyűjtemény lezárásra került, abba új példányt felvenni nem lehet. Azon esetekben, amikor bármi probléma volt a jelzettel, például a jelzet hibás volt, a példányok maradtak az „U=EK raktár” gyüjteményben. Ilyenkor egyenként történt a javítás, majd ezt követően a gyüjteménybe mozgatás.

A gyüjtemények rendezése után megtörtént számítógépek és az idöközben beszerzett nyomtatók beállítása és paraméterezése a két raktárszinten. Ezzel párhuzamosan határoztuk meg a nyomtatott kérőlap adattartományát. A cél az volt, hogy mind olvasói, mind példány oldalról olyan adatok kerüljenek a kérőlapra, amelyek egyértelmüen azonosítják a kikérőt és a kért 
dokumentumot is, megadják a kikéréshez kapcsolódó időket és mutatják az átvételi helyet is. Ezek alapján a kérőlapra az alábbi adatok kerültek:

- szerzö,

- cím,

- jelzet,

- gyüjtemény,

- példánystátusz,

- kérés kezdete,

- kérés vége,

- kérés ideje,

- nyomtatás ideje,

- átvétel helye,

- olvasó neve,

- olvasó azonosítója,

- olvasó vonalkódja.

Az adatok meghatározása után történt a kérölap méretezése és a nyomtatási beállítások megadása. Az adatok sorrendjét úgy jelöltük ki, hogy azok elrendezése a kérőlapon optimális legyen. Abban az esetben, ha az adott sorhoz nem tartozik adat (például szerző), akkor az a kategória nem kerül rá a kérőlapra.

Az Aleph-ben történt meg a jogosultságok beállítása is. Olvasói státusz oldalról mindenkinek engedtük az elektronikus dokumentumkikérést. Itt egységesen adtuk meg a kikérhető dokumentumok számát, amit lehetőség van emelni, illetve csökkenteni olvasói státuszonként vagy együttesen is.

Példánystátusz és a gyüjtemények esetében volt olyan, ahol engedtük (például 21 = kölcsönözhető példánystátusz; U3 gyüjtemény), és volt olyan, ahol tiltottuk a kikérést (például 62 = periodika leltár példány; $\mathrm{SINF}=$ Segédkönyvtár Informatika). Azon példányok esetében, amelyek a példánystátusz mellett rendelkeztek feldolgozási státusszal is, minden esetben tiltottuk a kikérést.

Az elektronikus dokumentumkikérés során beérkezett kéréseket az Aleph-ben beállított szerviz hívja le. A lekérdezés gyakoriságát 1 percben határoztuk meg. Ennek alapján a lefutó szerviz percenként vizsgálja, hogy érkezett-e kérés az adott időszakban. Ha igen, akkor ez(eke)t a két nyomtató valamelyikére küldi. 


\section{A fejlesztés 4. szakasza}

Ebben a szakaszban történt meg az elektronikus dokumentumkikérés ürlapjának kialakítása. A korábban tervezett lépéseket nézve a bejelentkezés után, a dokumentum kikeresése, majd kiválasztás után az engedélyezett esetekben a példánynál jelenik meg a „kikérés” felirat. Az olvasó erre kattintva tudja kikérni az adott példányt a felugró ürlapon.

Az ürlap kialakításakor törekedtünk arra, hogy:

- csak olyan adatok legyenek rajta, amelyek a kikérésnél fontosak,

- az ürlap legyen átlátható,

- az olvasónak minél kevesebb adatot kelljen saját magának beírnia,

- amit lehet, automatizáljunk.

Ennek megfelelően az alábbi ürlapot alakítottuk ki:

Elôjegyzés, kikérés - Czinki-Vietorisz Gabriella

(1) Ha kérdése van, irjon!

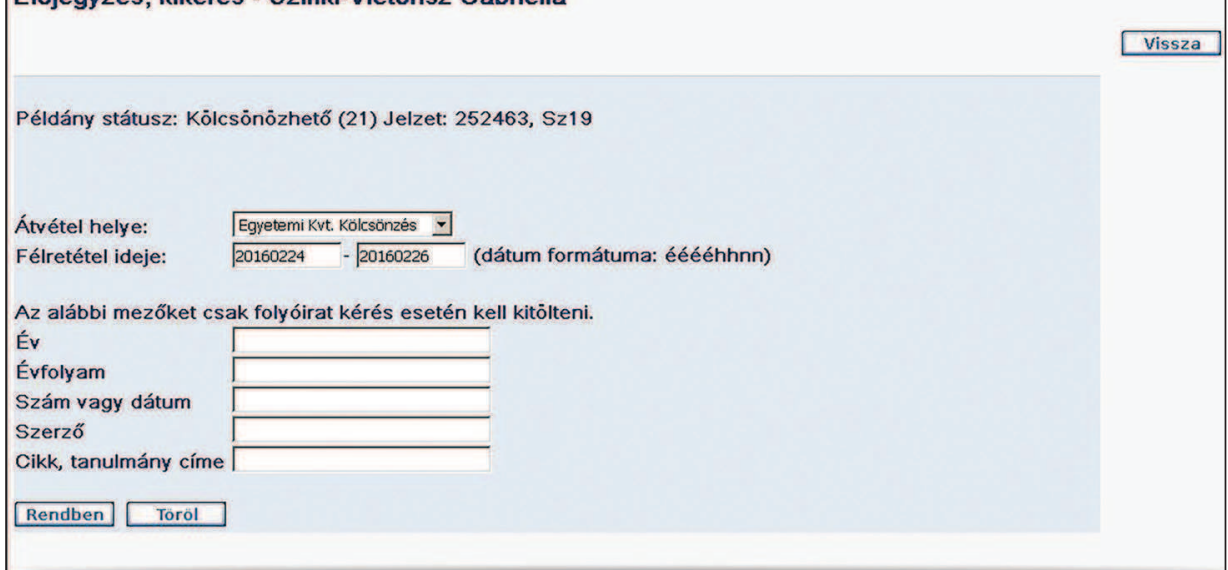

1. ábra. Képernyőkép ${ }^{1}$

Az ürlapon megtalálható a bejelentkezett olvasó neve, a kikért példány státusza (Kölcsönözhető, 21), a kiválasztott dokumentumhoz tartozó példányok jelzetei (254377, Sz19). Az „Átvétel helye” mezőben két lehetőség közül lehet választani: Egyetemi Könyvtár Kölcsönzés és Egyetemi Könyvtár Olvasóterem. Abban az esetben, ha az olvasó helyben használható példánystátuszú dokumentumot kér ki, az „Átvétel helye” automati-

${ }^{1}$ Elektronikus dokumentumkikérés ürlapja. Forrás: www.opac.elte.hu. [2016. 02. 25.] 
kusan az Egyetemi Könyvtár Olvasóterem lesz. Ha a példánystátusz ettől eltér, akkor lehet a két opció közül választani. A „Félretétel ideje” mező beállítása automatikus, a Könyvtárhasználati Szabályzatban foglaltak szerint első esetben 2, második esetben 10 nyitvatartási nap. Ha az olvasó nem időszaki kiadványt kér ki, akkor a „Rendben” gombra kattintással indítja a kérést, s az rögzül a nevénél.

Időszaki kiadvány esetében a kikérés menete kétféle lehet.

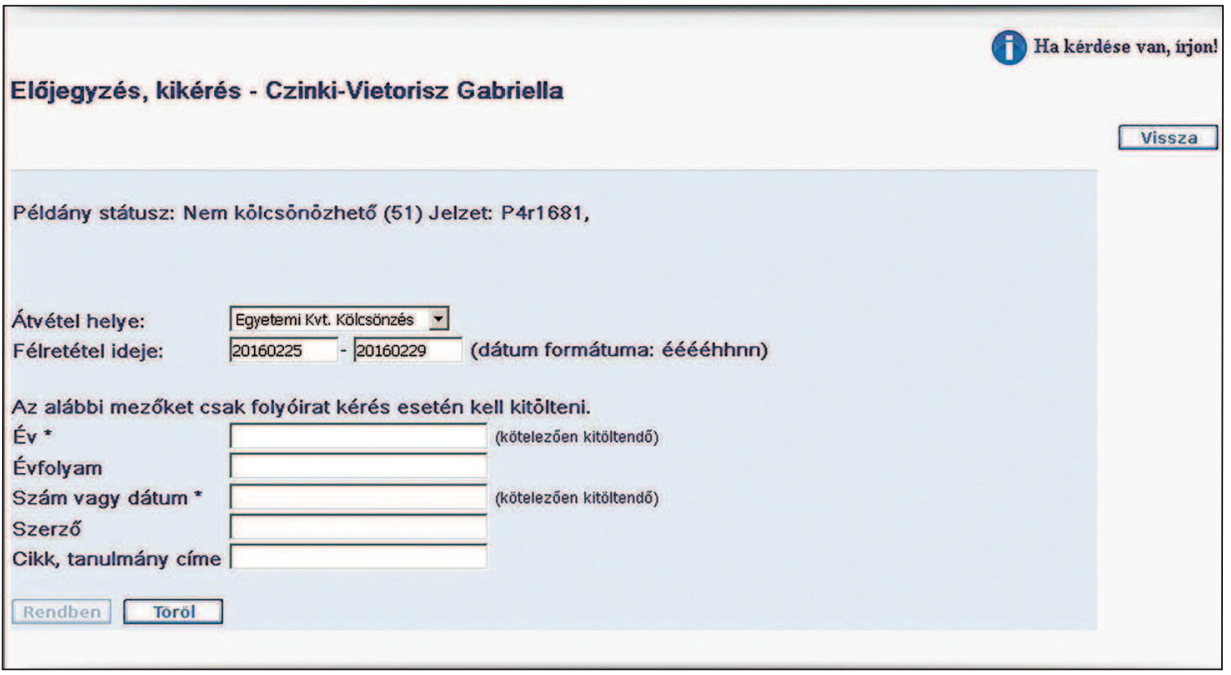

2. ábra. Képernyőkép ${ }^{2}$

Ha az olvasó olyan időszaki kiadványt kér ki, amelyben összevont adatok vannak, vagyis a példányhoz egy tól-ig-időszak tartozik (pl. 1. évf. 2000. - 15. évf. 2014.), akkor az ürlap második részében lévő mezők közül a kötelezőket ki kell töltenie. Ezeket a mezőket külön is megjelöltük * (csillaggal), és a sor végén zárójeles megjegyzés is utal a kitöltésre. Amíg az olvasó nem tölti ki ezeket a mezőket, addig az ürlap alján lévő „Rendben” gomb nem lesz aktív, így a kérés nem indítható a raktárba. Ha a mezők kitöltése megtörtént, akkor a „Rendben” gomb aktív lesz, így a kérés már rögzíthetö.

A másik lehetőség időszaki kiadvány esetében, ha a példányhoz tartozik egy évfolyam, egy év és egy szám. Ekkor a kötelező mezőkbe ezek

${ }^{2}$ Elektronikus dokumentumkikérés ürlapja. Forrás. www.opac.elte.hu. [2016. 02. 25.] 
az adatok automatikusan átemelődnek, és mivel helyben használható példányról van szó, az automatikus beállítások megtörténnek az „Átvétel helye” és a „Félretétel ideje” mezőkben, így az olvasónak a „Rendben” gomb megnyomásával lehetősége van a kérés indítására.

\section{A fejlesztés 5. szakasza}

Akár olvasói, akár példány oldalról előfordulhat, hogy a kikérésnek akadálya van. Ebben a szakaszban az ehhez kapcsolódó tájékoztató szövegeket készítettük el és állítottuk be a web-OPAC-ban. Az olvasó részéről akadály lehet a tagság lejárata, vagy az, hogy elérte az engedélyezett kikérések számát. Mindkét esetben megjelenik a tájékoztató felirat, mely a tényleges problémát vagy problémákat jelzi az olvasónak. Példány oldalról jeleztük azt, ha az egyes példányok olyan gyüjteményben vannak, amelyek nem raktáriak, hanem a polcról levehetők. Ide tartoznak a Folyóiratolvasó, az Olvasóterem és a Szabadpolc gyüjtemények.

A „Kötészeten”, „Kötésre előkészítve” és „Katalogizálás alatt” feldolgozási státuszú példányok esetében nem jelenik meg a kikérési lehetőség. Ez a státusz nem állandó státusza a példányoknak, de olyan munkákat jeleznek, amelyek ideje alatt a példány nem elérhető. Ha a nevezett munkák elkészültek, a dokumentumokról ez a státusz törlődik, és csak a példánystátusz marad. Az ilyen feldolgozási státuszú dokumentumoknál az olvasót a könyvtároshoz irányítjuk, aki az egyes nyilvántartásokból, illetve egyeztetések után meg tudja mondani, hogy a keresett mü mikor lesz elérhető.

Vannak olyan dokumentumok, amelyek külső raktárban találhatók. Ezek a Folyóirat külső raktár és az EK, külső raktár gyüjtemények példányai. Több tényező is befolyásolja, hogy ezeket mikor tudják az Egyetemi Könyvtárba beszállítani. Ilyen esetekben is helyeztünk el tájékoztatást, melyben az olvasót szintén a könyvtároshoz irányítjuk.

\section{Olvasói oldal, könyvtárosi oldal}

Az olvasó a web-OPAC-ban a bejelentkezés után az „Olvasójegyem” menüben a „Kikérések, előjegyzések” sorra kattintva tudja megnézni, hogy mely kikérések vannak a nevén. Lehetősége van törölni, ha a kikért példányra nincs szüksége a továbbiakban.

Könyvtárosi oldalról indulva az Aleph-ben az olvasó adatlapját megnyitva láthatók a kikérések. A könyvtárosnak lehetösége van törölni a ki- 
kérést, ha az olvasó ezt kéri tőle. A kölcsönzési müvelet automatikusan törli a kikérést az olvasó nevéröl. Ha a félretételi idő letelik, a törlés automatikusan megtörténik.

\section{A fejlesztés 6. szakasza}

Az olvasói tájékoztatás több formában valósult meg:

- az olvasók szöveges tájékoztatást kaptak,

- az elektronikus dokumentumkikérés tájékoztatóját megjelentettük az EKSz-portálon: http://konyvtar.elte.hu/hu/ekerolap,

- szóróanyagokat helyeztünk el a könyvtár szolgáltatási pontjain,

- az olvasóknak küldött e-mailekben helyeztük el a portálhír linkjét.

\section{Visszajelzések, statisztika}

Az olvasói visszajelzések folyamatosan érkeznek a könyvtárba. Ezek legnagyobb része pozitív, az olvasók elégedettek, jó fejlesztésnek tartják a szolgáltatást. 2015. januártól júliusig az összes raktári dokumentumkikérés $60 \%$-át kérték ki az olvasók elektronikus dokumentumkikéréssel.

Az e-mailes kérések száma folyamatosan csökkent:

- 2013. január-június: 1060 db dokumentum

- 2014. január-június: 914 db dokumentum (-14\%)

- 2015. január-június: 194 db dokumentum (-79\%)

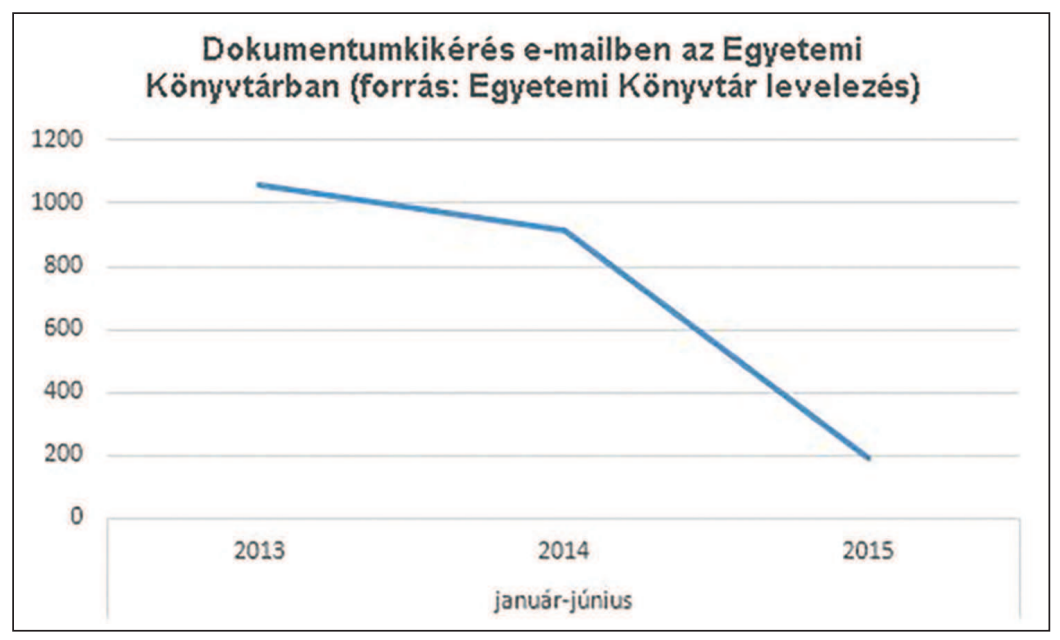

3. ábra. Dokumentumkikérés az Egyetemi Könyvtárban (az adatok forrása: Egyetemi Könyvtár - levelezés) 
Köszönet

Az egyéb munkáink mellett az elektronikus kérőlap bevezetésének folyamata a tervezéstől a tesztelésen át a megvalósításig nagyjából 1 évet ölelt fel. Köszönetemet fejezem ki alábbi kollégáimnak és a további közremüködöknek az elvégzett munkáért, amelynek segítségével a projektet sikeresen megvalósítottuk.

- Cerva Csaba - Egyetemi Könyvtár Informatikai és Fejlesztési Osztály: Aleph, hardver;

- Polán Attila - Tanító és Óvóképző Kar Kari Könyvtár: web-OPAC;

- Székelyné Török Tünde - Egyetemi Könyvtár Gyüjteményszervezési Osztály: szakmai tanácsadás;

- Szépvölgyi Katalin - Egyetemi Könyvtár Gyüjteményszervezési Osztály Folyóirat csoport: szakmai tanácsadás;

- Varga Klára - Egyetemi Könyvtár Informatikai és Fejlesztési Osztály: szakmai tanácsadás;

- BME OMIKK;

- Ex-Lh Számítástechnikai Kft.;

- Országgyülési Könyvtár.

\section{Rezümé}

Az Egyetemi Könyvtári Szolgálat K21 minőségfejlesztési munkacsoportjai több alkalommal végeztek kérdőíves felmérést, melyben több felhasználó is kérte a dokumentumok kikérését megkönnyítő szolgáltatás bevezetését, és ezt az igényt a napi kiszolgálás során is jelezték a könyvtárosok felé. Ehhez kapcsolódva a tanulmányban bemutatom az elektronikus dokumentumkikérés bevezetésének folyamatát a tervezéstől, az egyeztető megbeszéléseken át a tesztelésig, majd a megvalósításig. Kitérek a korábbi dokumentumkikérés gyakorlatának ismertetésére. Részletesen írok az elektronikus kikéréshez kapcsolódó módosításokról, amelyeket az Aleph IKR-ben végeztünk el, melyek közül a lényegesebbek az új gyüjtemények kialakítása, egyes gyüjtemények rendezése, valamint a jogosultságok változtatása olvasói és példány oldalról is. Vázolom a web-OPAC-ban történt új beállításokat, módosításokat, az ürlap mezőinek kialakítását időszaki kiadvány és egyéb dokumentumok esetében, a mezők elnevezését, a kötelező mezők megjelölését, az automatikus beállításokat. Kitérek a nem raktári, a külső raktári és a bármely okból nem kikérhető dokumentumok esetében beállított üzenetekre. Tanulmányomat az olvasói visszajelzések és a statisztikai adatok ismertetésével zárom. 


\section{Service development adjusted to the needs of the library users in the University Library}

The K21 quality development groups of the University Library Service (EKSZ) have carried out surveys several times. Many of those who filled in the questionnaires and those who visited the library in person asked for the introduction of services that make document requesting easier. In this study I describe every aspect of this installation such as planning, consulting, testing and programming. I also present the old practice of document requesting. I write in detail about changes that were made in the Aleph ILS (integrated library system), such as the creation of new collections, arranging collections and making changes in the entitlements from reader and copy side. I also mention the new settings and modifications in web-OPAC, the creation of form fields in case of periodicals and other documents, the naming of the form fields, the marking obligatory fields and the automatic setup. I also present setup messages that contain information about documents that cannot be requested, and documents stored in off-site storages or at other places. Finally, I present statistics and the readers's feedback.

CZINKI-VIETORISZ GABRIELLA könyvtáros ELTE Egyetemi Könyvtár 